\title{
Applying music as a supplemental treatment in cancer care
}

\author{
JÁNOS KOLLÁR* \\ Institute of Behavioural Sciences, Semmelweis University, Budapest, Hungary
}

(Received: 20 September 2015; accepted: 16 January 2016)

\begin{abstract}
Theoretical background: Applying music as a supplemental therapeutic method is a flexible, patient-directed and adaptable, non-invasive treatment. Several forms of musical interventions are able to reduce distress, chronic pain, anxiety and depression.
\end{abstract}

Aim: The purpose of this review was drawing attention to the possibility of applying music as a supplementary, supportive treatment for cancer patients. The article would like to give a broader view of different fields of applying music in cancer treatment.

Methods: A search was made in Journal of Music Therapy, Music Therapy and Music Therapy Perspectives. Besides PubMed and Web of Knowledge were used for searching relevant articles reported in English and containing the expressions "music" and "cancer" or "music" and "psychooncology", or "music" and "oncology", or "music " and "tumor", or "music" and "tumour" in their titles. The searching process was closed in 2013. The articles were filtered by relevant content regarding the application of music in cancer treatment. The articles were considered as relevant 1) if they were focusing on any application of music in cancer treatment and 2) if they reported about original research results, so the reviews were filtered out of our selection. 61 articles were found of which 25 were considered as relevant for the review. The analysis of data was based on the following criteria: a) the aim of applying music with cancer patients, b) the applied method and period of intervention, c) number of participants and d) results.

Results: There is a significant improvement in quality of life of cancer patients receiving music as a supportive treatment. Both active and receptive forms of music therapy can be applied successfully either independently or with other therapies as a part of the supportive care.

Conclusion: Music applied by qualified music therapists in therapeutic circumstances can be suggested as a supportive treatment for cancer patients.

Keywords: music, cancer, distress, relaxation, depression, breast cancer, mastectomy

\footnotetext{
* Correspondence: dr. János Kollár, Institute of Behavioural Sciences, Semmelweis University, Nagyvárad tér 4, H-1089 Budapest, Hungary. E-mail: janoskollar@gmail.com
} 


\section{Theoretical background}

In the age of holistic approach of medicine the need for applying effective, non-invasive treatments is greater than ever. It is especially true in case of treating cancer patients when as the effect of isolation and treatment, physical and emotional changes even depression can be experienced very often (Addington-Hall, 2013). Applying music as a supplemental therapeutic method is a flexible, patient-directed and adaptable, non-invasive treatment (Gasenzer \& Neugebauer, 2011). Several forms of musical interventions are able to reduce distress, chronic pain, anxiety and depression (Nyer et al., 2013). It is also very important that during music therapy sessions the patient and family members may discover again their probably long forgotten connections to each-other. Music therapy has a significant role as a supportive therapy in palliative care (Gutgsell et al., 2013). When applied in a proper way it can make the patients realize their own possibilities in participating in their healing process.

\section{Aim}

The purpose of this review was drawing attention to the possibility of applying music as a supplementary, supportive treatment for cancer patients. The review would like to give a broader view of different fields of applying music in cancer treatment. It focuses on the different possible applications of music therapy such as applying it independently or with other therapies, the application of live versus recorded music, improving life quality of cancer patients and of their family members, a special field of how to apply music therapy with children having cancer, and took a short look into the application of Bonny Method of Guided Imagery and Music (Burns, 2001). An analysis was made focusing on a) the aim of applying music therapy with cancer patients, b) the applied method and period of intervention, c) number of participants and d) results.

\section{Methods}

A search was made in Journal of Music Therapy, Music Therapy and Music Therapy Perspectives. Besides PubMed and Web of Knowledge were used for searching relevant articles reported in English and containing the expressions "music" and "cancer" or "music" and "psychooncology", or "music" 
and "oncology", or "music " and "tumor", or "music" and "tumour" in their titles. The searching process was closed in 2013.

The articles were filtered by relevant content regarding the application of music in cancer treatment. The articles were considered as relevant 1) if they were focusing on any application of music in cancer treatment and 2) if they reported about original research results, so the reviews were filtered out of our selection. Sixty-one articles were found of which 25 were considered as relevant for the review. The analysis of data was based on the following criteria: a) the aim of applying music with cancer patients, b) the applied method and period of intervention, c) number of participants and d) results.

\section{Results}

\subsection{The multifunctional role of music}

Music can provide the paediatric and adolescent patients, their family members, and beloved ones with opportunities to explore and show their psychosocial, emotional, and physical needs. Such needs can be addressed through the use of receptive/listening, re-creative, and compositional methods (Daveson, 2001).

Creativity inspired by music can help cancer patients to face the disease (Daykin, McClean, \& Bunt, 2007). Soft music can be a useful supplement to analgesics as well (Huang, Good, \& Zauszniewski, 2010). Music provides opportunities also for experiencing feelings of control during a time of lossof control inflicted by the disease and ensuing experiences of illness (Rykov, 2008).

Some of the major goals of applying music in particular therapeutic applications in oncology settings can be: promoting expressions of emotions, relaxation, promoting expressions of spirituality or end of life concerns, promoting cognitive processing and expression of thoughts, serving as a social catalyst for family or group interactions, distracter, sensory stimulator, enhancement of immune functions, motivator for exercising and tool for learning (Kruse, 2003).

Chen, Wang, Shih, and Wu (2013) applied fifteen-minute music intervention on patients prior to radiation to investigate effects of music intervention on reducing pre-radiotherapy anxiety in oncology. Music therapy decreased State anxiety levels, Trait anxiety levels and systolic blood pressure in oncology patients who received the intervention. 
The nature of the music experience can provide a significant amount of creative energy that is usually lost in the hospital environment. Music not only enriches the quality of one's life but may help provide the impetus to live (Fagen, 1982). A survey of patients undergoing radiotherapy reported that majority of people favour background music during this treatment (Mowatt, 1967). Although it can't be considered as a classical music therapy but music in itself may have some therapeutic effects.

Kruse (2003) made a survey aiming at the replies of 164 music therapists working in the United States with oncology patients or persons with cancer. She identified the common music therapy interventions used in oncology such as relaxation, song writing, instrument playing, song-leading, lyric analysis, guided imagery and music instruction. The results suggest that relaxation, song writing and instrument playing are the most widely used by music therapists working with cancer patients. Other fields of application cover improvisation, music games, musical life review, producing "patientgenerated" music videos, toning, and music with art, theatre, or movement. Seventy percent of therapists stated that they prefer to use live music if possible.

Bailey (1983) compared the effects of live versus recorded music on hospitalized cancer patients. The patients were randomly selected and placed into two groups listening live or recorded music respectively. Each subject listened to 25 minutes of music. Mood states before and after the sessions were recorded on the Profile of Mood States (POMS) questionnaire (McNair, Lorr, \& Droppleman, 1992). The live and recorded pre- and post-music scores were compared. The participants in the live music groups reported significantly less tension-anxiety and more vigor than did the participants of the recorded music group. Moreover live music subjects reported significantly more changes in physical discomfort, changes in mood, and changes in mood for the better and recommended music sessions for others. Results emphasize the particular effectiveness of using live music vs. recorded music to assist in relieving tension and promoting vigor. Probably it is owing to the importance of the "human element" inherent in live music. Kollár (2007) proved to get similar results on the course of regular live concerts organized on Heamatology-Oncology Ward of Pediatric Clinics of Medical and Health Science Centre at the University of Debrecen.

It is not always easy to involve cancer patients in music therapy. The sessions must be prepared carefully and appropriate information must be given to the patients. O'Callaghan and Colegrove (1998) experienced that cancer patients are more willing to participate in music therapy sessions if the sessions are conducted in an open ward. This way the patients can hear the music before they actually meet the therapist. During therapy patients are asked about their musical preference, the sessions are interactive, and the therapist 
don't go too deep in discussing different music therapy methods or discussing too much about the physical pain of the patients.

Music therapy applied together with proper human care proved to be very effective in the research of Lai, Li and Lee (2012) when music intervention with nursing presence provided a friendly music experience to the listeners as measured on psycho-physiological indices (pulse, heart rate, depression, anxiety and sleep quality).

Naturally in music therapy session the therapist has to face the possible resistance of the patients to be involved. In a new and strange environment, like a hospital every new experience demands extra effort from the patients to accommodate to unusual and thus stressful methods. Thus the first task of a music therapist is dissolving the fear, resistance and anxiety by facilitating the emotional reactions of the patients. A strange environment can be made more pleasant by applying familiar stimuli like songs what the patients like.

Bailey (1984) published some case studies describing the importance of the use of songs in music therapy with cancer patients. Different feelings and emotions evoked by the songs can provide frameworks for tension release, integration and pleasure. During the sessions patients and family members can experience feelings of inner peace, well-being, and relief which make them realize their own possibilities in participating in their healing process. Bailey also emphasize the importance of the three basic stages of a music therapy process, namely a) the contact phase, b) the phase of awareness, and c) the phase of resolution. In the first phase the therapist and the patient build a strong therapeutic relationship, in the second one the patient focuses more his/her own feelings, desires, and experiences under the guidance of the music therapist and in the last stage provides a feeling of relief and self-fulfilment for the patient.

Lee, Bhattacharya, Sohn and Verres (2012) investigated the possibilities of reducing distress effects of chemotherapy by using monochord sounds and progressive muscle relaxation for alleviating pain, enhanced body perception and relaxation. They used two randomized groups of patients treated by chemotherapy. The first group listened to monochord sounds and the second listened to progressive muscle relaxation during chemotherapy. Patients in both groups showed significant improvement in their physical and psychological states and in state anxiety, thus it can be ascertained that listening to monochord sounds and practising progressive muscle relaxation have a useful and comparable effect on gynaecologic oncological patients during chemotherapy.

Lai, Chao, Yang and Chen (2010) demonstrated the effectiveness of music therapy for lung cancer patients as low-cost end-of-life palliative care for dyspnoea. 
Music therapy can be applied also together with other psychotherapies. Magill, Levin and Spodek (2008) investigated the conjoint effect of cognitive behaviour therapy (CBT) and music therapy and found that the application of the two methods in combination could reduce distress of critically ill cancer patients regardless of their stage of illness.

In another study it was proven that spiritual experiences evoked by music have a great impact on physical and emotional well-being of terminally ill patients. Thus the application of music in palliative care has also to be taken into consideration (Renz, Schutt Mao, \& Cerny, 2005).

Music therapy proved to be effective not only for human cancer patients but also for animals having cancer. The effects of music on the immune system and cancer development were evaluated in rodents subjected to sound stress (Nunez et al., 2002). According to the results music reduced the suppressive effects of stress on immune parameters in mice and decreased the enhancing effects of stress on the development of lung metastases provoked by carcinosarcoma cells. It also enhanced the immune parameters and the anti-tumour response in unstressed rodents.

\subsection{Application of music with children having cancer}

Cancer patients have to face with extremely high level of emotional distress during and even after the necessary treatments; therefore their immune and endocrine functions significantly decrease. It is especially true in cases of children. During the isolation what is an unpleasant but necessary part of the treatment these children may experience a number of negative emotional effects such as losing social contacts, suffering from lack of stimulation and having less opportunities for participating in less physical activities. Their emotional reactions given to such circumstances often include loneliness, depression, rejection, anger, and confusion. During the cancer treatment changes in the child's physical appearance occur, such as loss of hair, yellowing or peeling of the skin, lumps, scars, and bruises. These conditions often affect the child's self-concept negatively (Brodsky, 1989). Based on the pre- and post-music therapy measures Barrera, Rykov and Doyle (2002) experienced positive impact of music therapy on the child's well-being. Nguyen, Nilsson, Hellstrom and Bengtson (2010) were working with children having leukaemia. They investigated if music therapy influences pain and anxiety in children undergoing lumbar punctures. Their results showed lower pain scores, and heart and respiratory rates in the music group during and after the lumbar puncture. The anxiety scores were lower in the music group both before and after the procedure. 
Kemper, Hamilton, McLean and Lovato (2008) investigated the effect of music on paediatric oncology outpatients. Patients with leukaemia participating in maintenance or consolidation outpatient treatment served as their control on a visit two. During visit 1, children rested for $20 \mathrm{~min}$; during visit 2, for 20 min they listened to music designed to increase vitality and improve heart rate variability. Relaxation was more effective by using music. The heart rate variability parasympathetic parameter was significantly lower with music.

A music therapy program for cancer patients should not focus only on the patients themselves but also their family members. Slivka and Magill (1986) were working with children of cancer patients by using music therapy and social work methods. As tools of music therapy they applied song writing, playing musical instruments, and singing familiar songs. By their case studies the authors give a proof of the effectiveness of conjoint use of social work and music therapy. The verbal and nonverbal therapeutic methods can help the children to express their hidden feelings and thoughts and give the opportunity for experiencing intimacy lacking in their lives. As a result of such combined treatments the patients and their family members can experience a kind of social support, and they can get a greater opportunity for expressing their needs on both verbal and nonverbal levels. In another experiment (O'Callaghan, O'Brien, Magill, \& Ballinger, 2009) mothers and fathers having haematological or metastatic diseases songs for their children. Parents' song lyric messages may support their children during the parents' illnesses and through the children's developmental transitions and possible bereavement. According to the results of Magill (2009) music therapy in palliative care strives to promote well-being and quality of life for patients and caregivers as well.

\subsection{The application of Bonny Method of Guided Imagery and Music}

Burns (2001) gives a report about the effectiveness of the Bonny Method of Guided Imagery and Music (GIM) in alleviating mood disturbance and improving quality of life in cancer patients. GIM is a music therapy method utilizing Western Art music to explore imagery and emotional expressions of patients. The developer is Helen Bonny, music therapist who created GIM as a possible alternative to LSD psychotherapy (Bonny, 1980). Blake and Bishop (1994) give a short but detailed summary of the method. A GIM Session consists of four parts. No. 1 is a verbal dialogue between the patient and the therapist. It gives the opportunity for the therapist to assess the pa- 
tient's emotional status, ego strengths, coping mechanisms, and to identify a specific goal for the session. No. 2 is based on a relaxation exercise and an imagery induction. During the relaxation phase the patient can reach the level of an altered state of consciousness and may evoke feelings of vulnerability that can be frightening or agitating. In this part of the program the therapist prepares the patient for the music by giving an image which should be specific and reflective of the therapeutic goal. No. 3 is the music/ imagery phase when the patient listens to the music and describes the emerging images or feelings. No. 4 is the final phase when the material from the session is processed. The interpretation and insight of the patient are in the focus of this part. The therapist helps to build connections between the patient's imagery experience and the session goal. It is essential for initiating integration into the patient's daily life and for reinforcing reclaimed or newly found inner resources. In the experiment of Burns (Burns, 2001) each of the experimental subjects participated in 10 weekly GIM sessions individually. All patients completed the Profile of Mood States (POMS) (McNair et al., 1992) and Quality of Life-Cancer (QOL-CA) (Padilla, Grant, Ferrell, \& Presant, 1996) questionnaires pre-test, post-test before and after the treatment, and then came a 6-week-long follow-up. Individuals who participated in GIM sessions reached higher mood and quality of life scores at posttest than the members of the control group. Moreover, mood and quality of life scores continued to improve in the experimental group, even after sessions were complete. The results suggest that GIM was effective in improving both mood and quality of life in these cancer patients.

In the experiment of Waldon (2001) the oncology patients participated in a 10-week-long study consisting of 8 music therapy sessions applying both active ("music making") and receptive ("music responding") therapeutic methods. The Profile of Mood States-Short Form (POMS-SF) (McNair et al., 1992) was used to assess changes in participants' mood states. The results showed significant improvement of the participants' mood. Applying the "music making" method, comparisons between pre-test and post-test scores showed a statistically significant improvement in mood state. A similar significant effect was found in the "music responding" condition between the pre-test and post-test scores.

\subsection{Application of music with breast cancer patients}

Breast cancer is considered to be the most dangerous cancer among women worldwide. Both the disease and the treatment have a profound impact on the patients' psychological well-being and quality of life. The incidence of 
depression is very frequent among breast cancer patients and it prolongs the duration of hospital stay. The study of Zhou, Li, Yan, Dang and Wang (2011) gives a report of the effective application of music therapy on depression and duration of hospital stay of female patients with breast cancer after radical mastectomy.

The relaxing effect of music is one of the most well-known and common applications of music therapy. Chuang, Han, Li and Young (2010) proved that music therapy can be clinically useful for promoting relaxation sensation and increasing parasympathetic nervous system activity in treated cancer survivors.

The study of Chuang, Han, Li and Young (2011) aims to determine if music therapy intervention improves autonomic function in anthracyclinetreated breast cancer patients, and if so, whether such improvements persist after cessation of the music therapy sessions. The patients had undergone mastectomy or breast-conserving treatment and adjuvant chemotherapy; they attended weekly music therapy interventions for 8 weeks. Each of the sessions lasted 2 hours. Electrocardiogram traces (5 minutes) for heart rate variability analysis were recorded 4 times: prior to the first music session, after the fourth music session, after the eighth music session and 4 weeks after the completion of music therapy. The standard deviation of normal intervals and the total power of heart rate variability parameters, related to global autonomic function, were significantly higher after the eighth music session than prior to the first music session. Global autonomic function and parasympathetic activity did not change significantly 4 weeks after the completion of music therapy relative to the value measured prior to the first music session. The study could provide evidence of the benefits of music therapy for anthracycline-treated breast cancer survivors.

$\mathrm{Li}$, Zhou, Van, Wang and Zhang (2011a) found music therapy as having positive effects on decreasing state anxiety score of breast cancer patients. They conducted a randomized controlled trial. The experimental group received music therapy in addition to routine nursing care. The control group received only routine nursing care without music therapy intervention. A standardized questionnaire and the State Anxiety Inventory were applied in the study. The state anxiety score was measured at pre-test (on the day before radical mastectomy) and at three post-tests (on the day before patients were discharged from hospital, the second and third time of admission to hospital for chemotherapy respectively). According to the result of the study the mean state anxiety score was significantly lower in the experimental group than those in the control group at each of the three post-test measurements. Li et al. (2011b) investigated also the effects of music therapy on pain reduction in patients with breast cancer after radical mastecto- 
my under similar circumstances and they found that after music therapy, the main pain scores in the intervention group decreased considerably up to 2 months after radical mastectomy.

Binns-Turner, Wilson, Pryor, Boyd and Prickett (2011) give a report about a study involving 30 women undergoing mastectomy because of breast cancer to evaluate the effects of a perioperative music intervention on changes in mean arterial pressure, anxiety, and pain. Their results also support the suggestion of using music therapy in such cases since the researchers report about reduction of mean arterial pressure, anxiety, and even pain of the members of the group received music intervention. Table 1 gives an analysis of the articles mentioned above describing different methods of music interventions with cancer patients described above. 


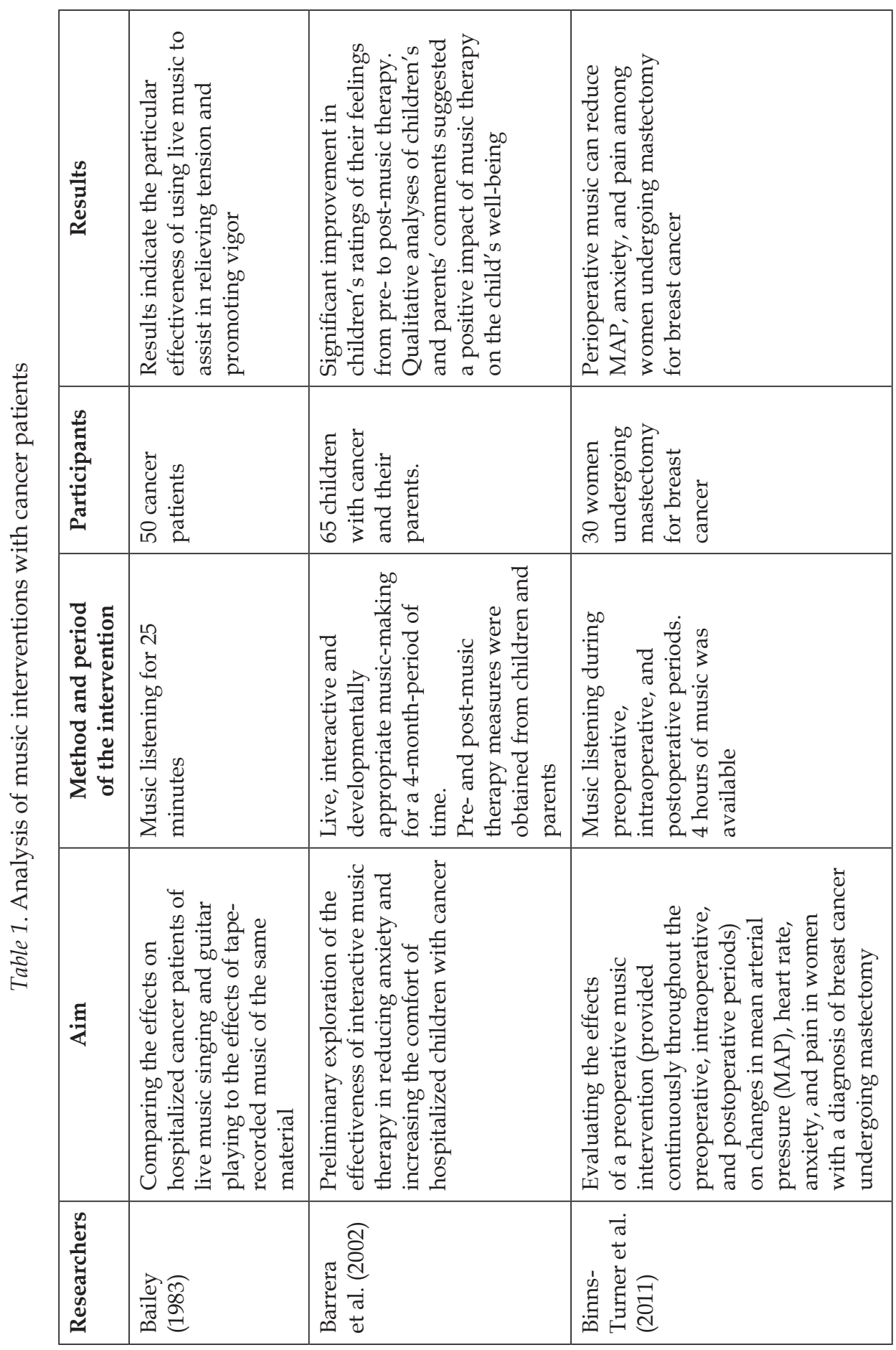




\begin{tabular}{|c|c|c|c|}
\hline 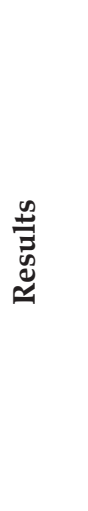 & 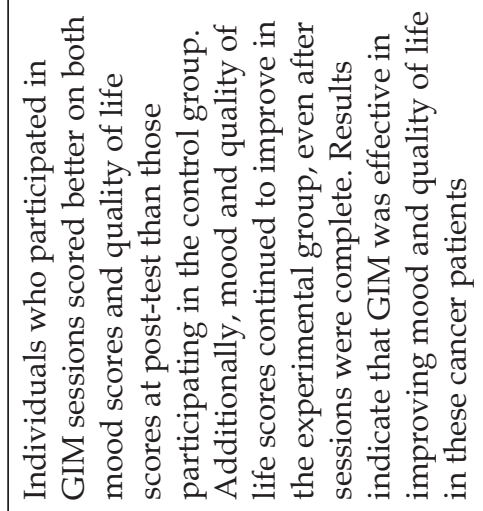 & 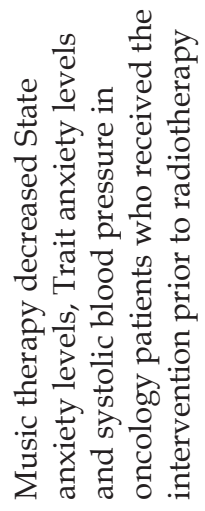 & 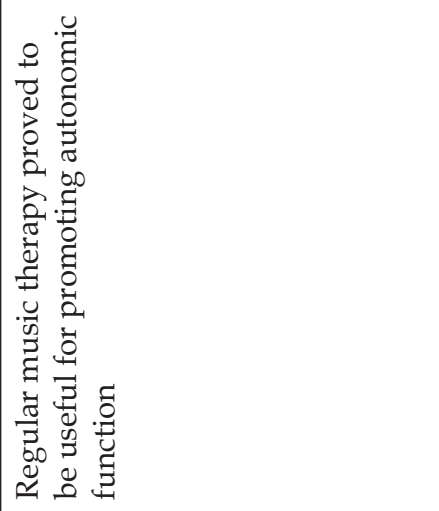 \\
\hline 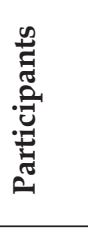 & 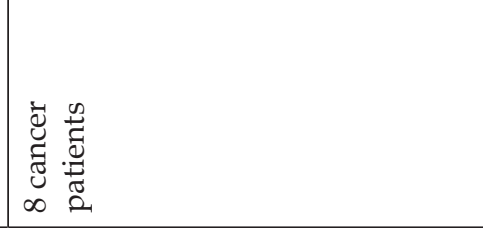 & 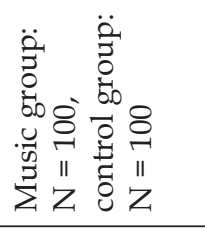 & 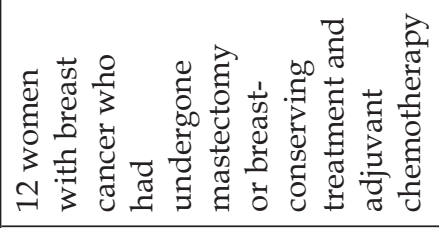 \\
\hline 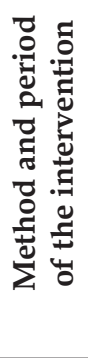 & 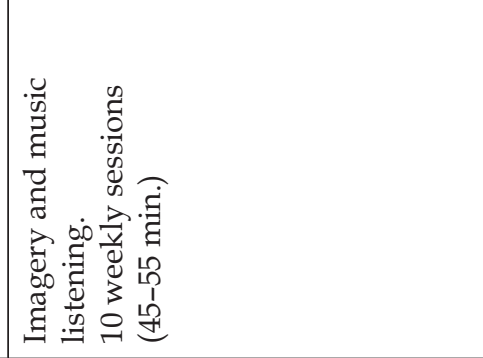 & 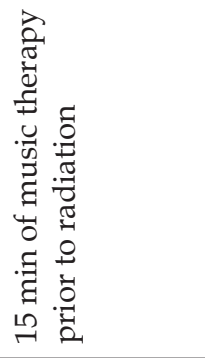 & 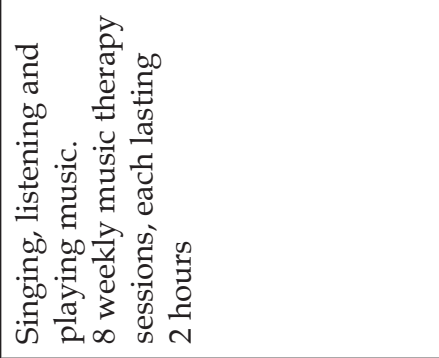 \\
\hline$\stackrel{\xi}{Z}$ & 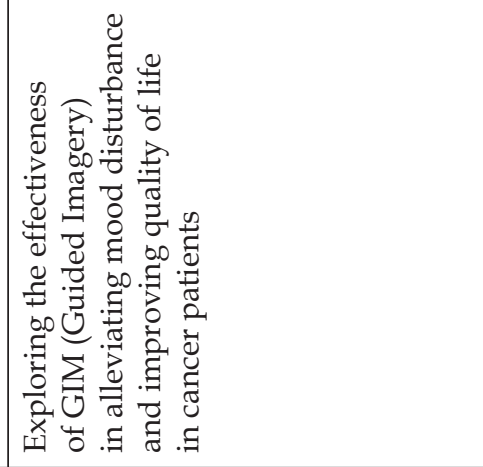 & 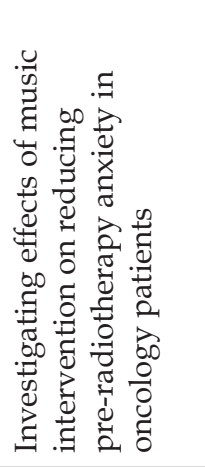 & 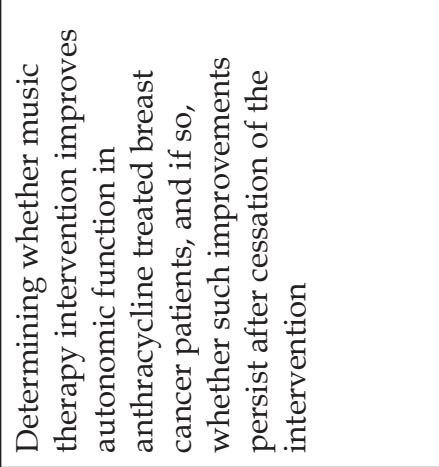 \\
\hline 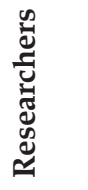 & 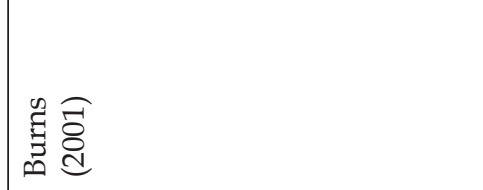 & 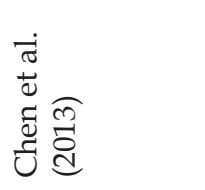 & 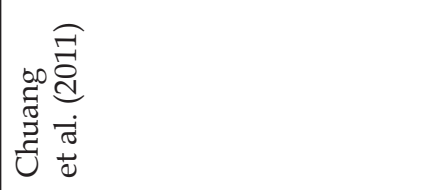 \\
\hline
\end{tabular}




\begin{tabular}{|c|c|c|c|}
\hline & 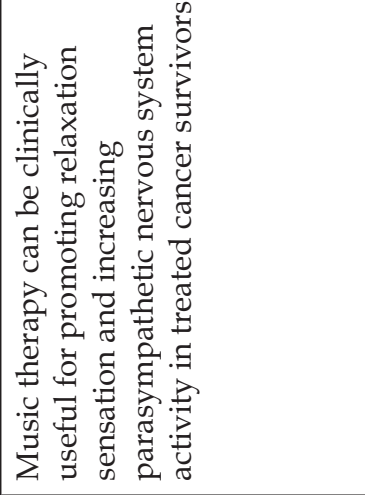 & 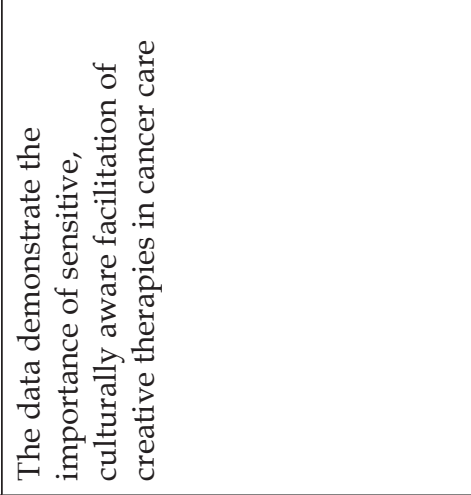 & 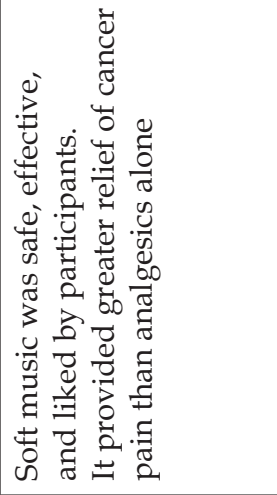 \\
\hline 范 & 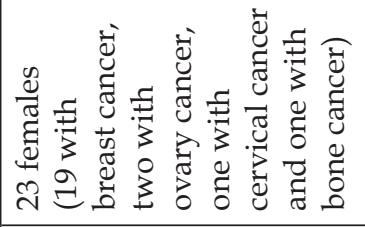 & 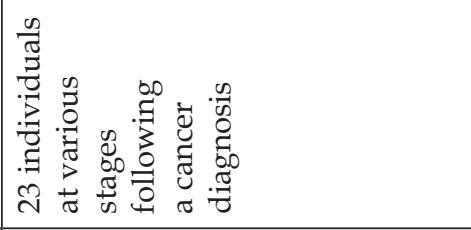 & 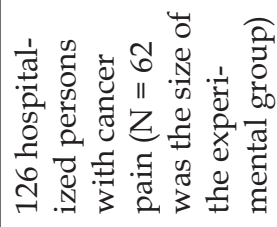 \\
\hline 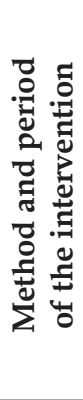 & 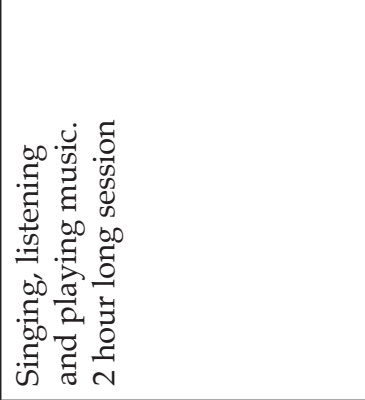 & 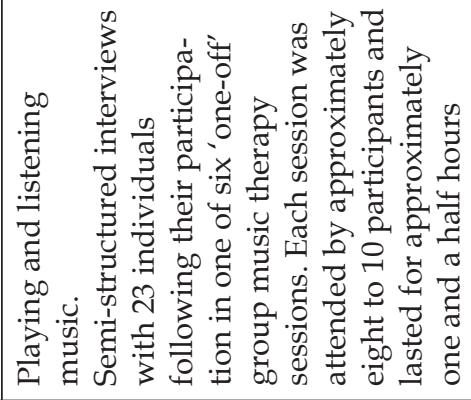 & 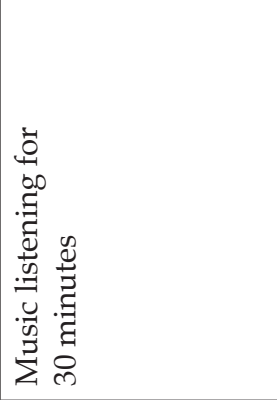 \\
\hline 浔 & 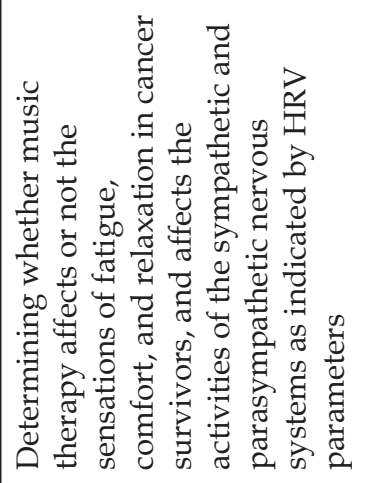 & 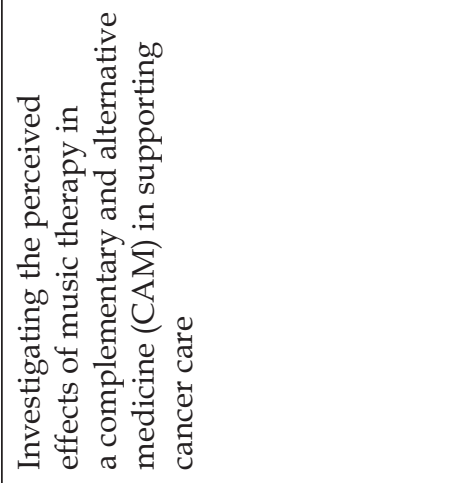 & 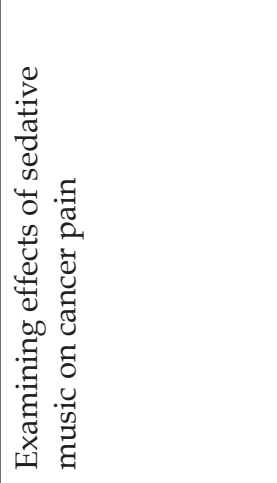 \\
\hline 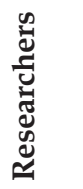 & 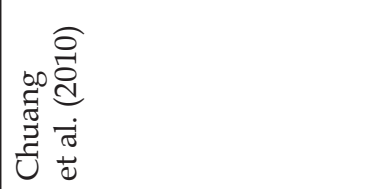 & 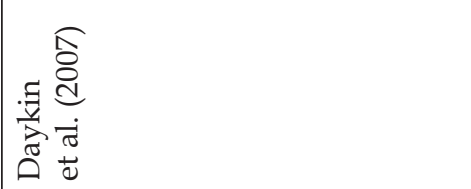 & 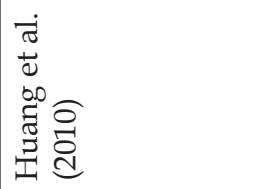 \\
\hline
\end{tabular}




\begin{tabular}{|c|c|c|}
\hline & 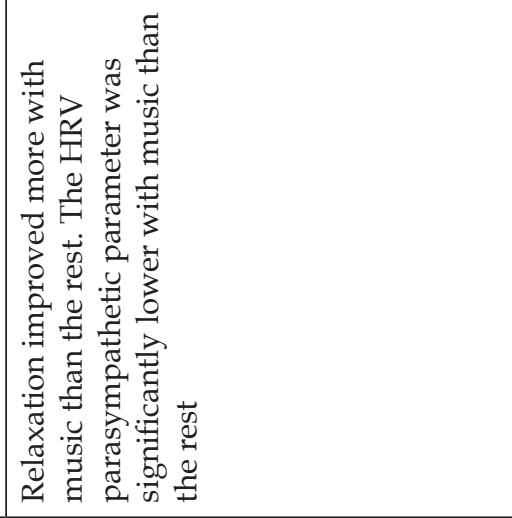 & 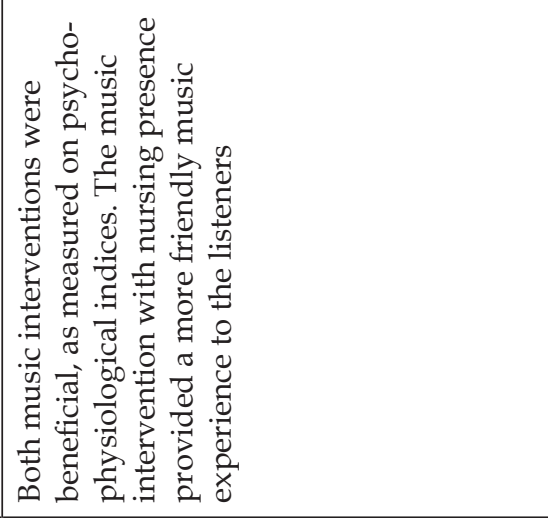 \\
\hline 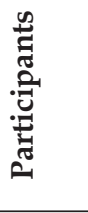 & 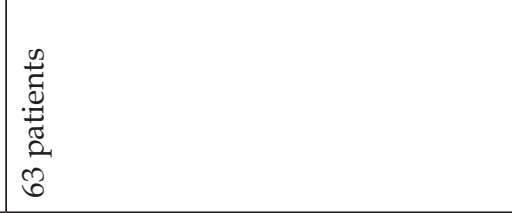 & 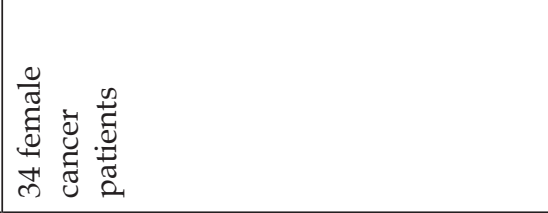 \\
\hline 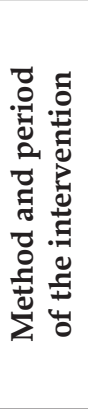 & 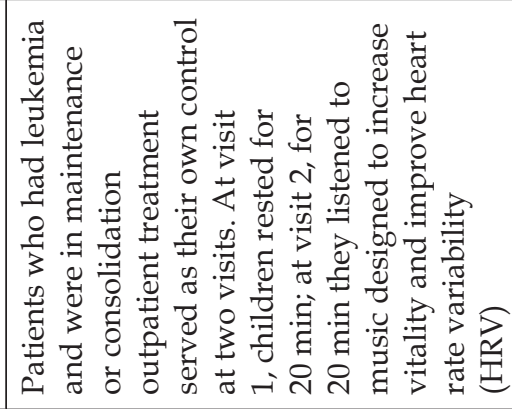 & 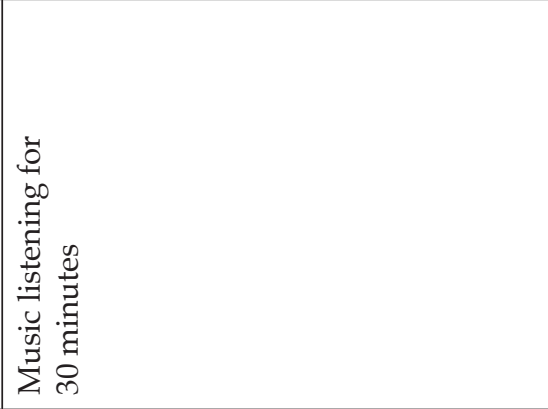 \\
\hline 罗 & 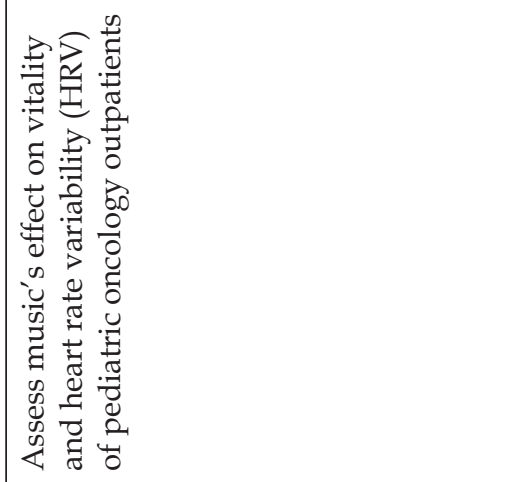 & 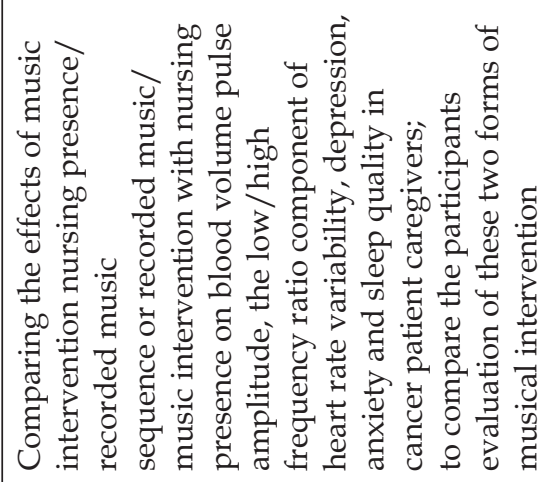 \\
\hline 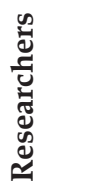 & 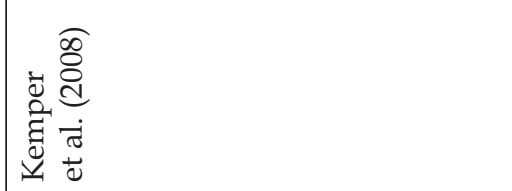 & 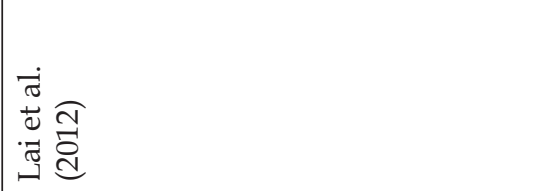 \\
\hline
\end{tabular}




\begin{tabular}{|c|c|c|c|}
\hline & 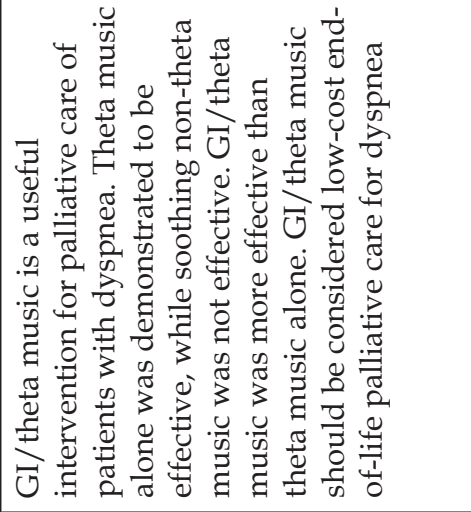 & 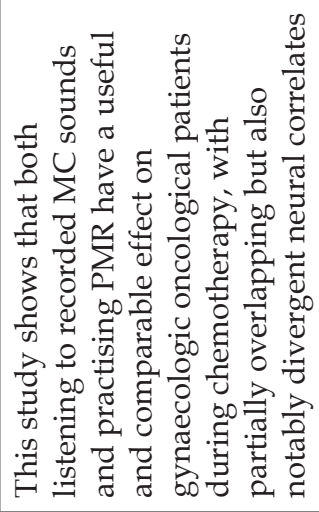 & 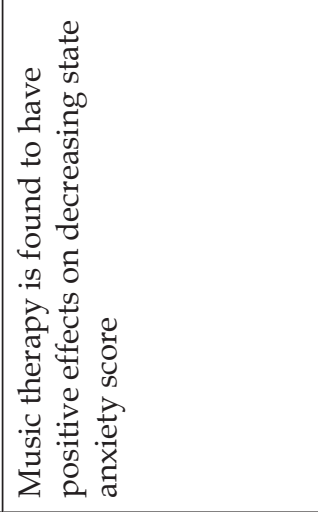 \\
\hline 范 & 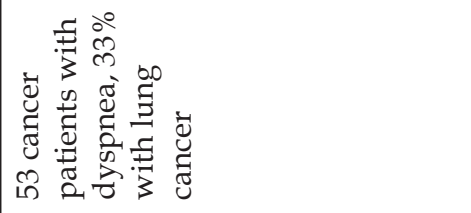 & 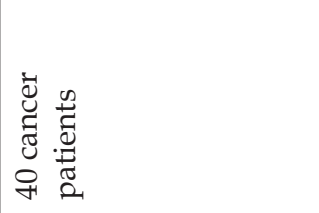 & 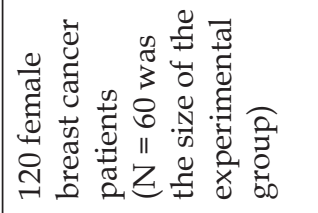 \\
\hline 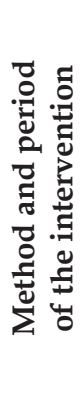 & 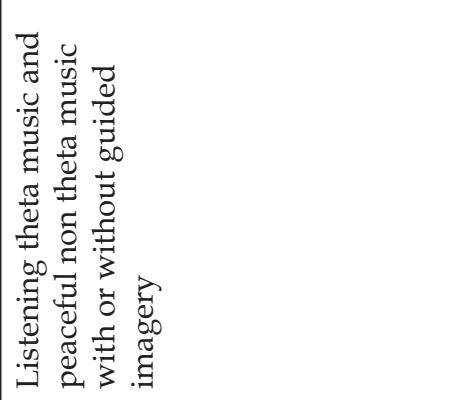 & 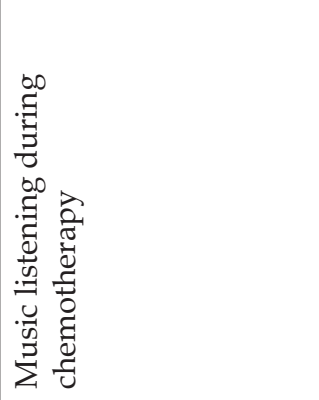 & 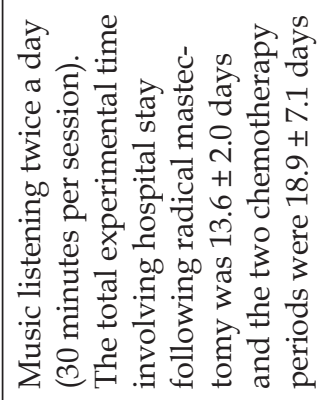 \\
\hline 浔 & 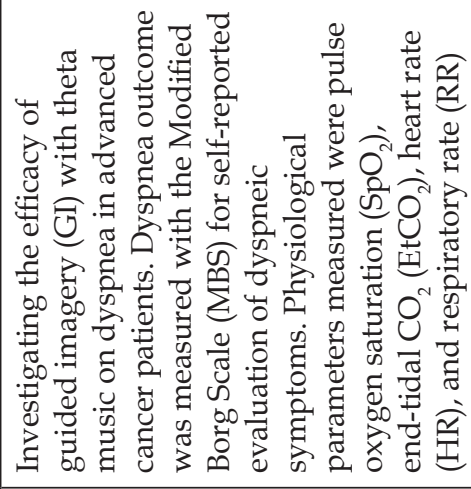 & 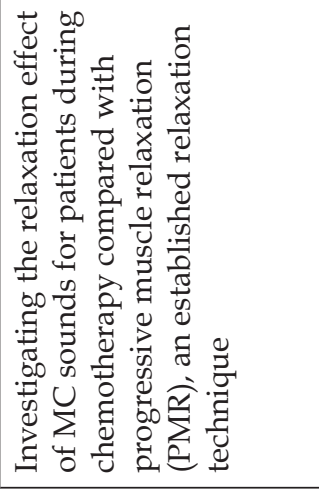 & 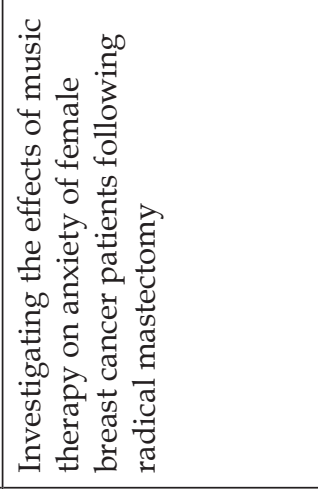 \\
\hline 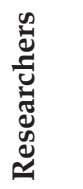 & 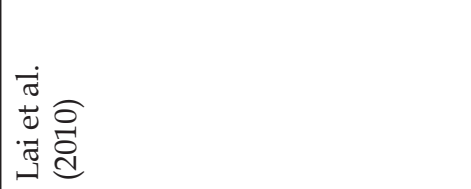 & 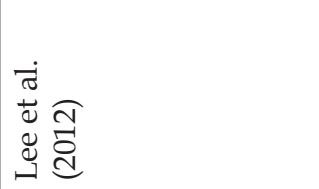 & 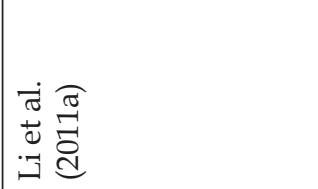 \\
\hline
\end{tabular}




\begin{tabular}{|c|c|c|c|}
\hline & 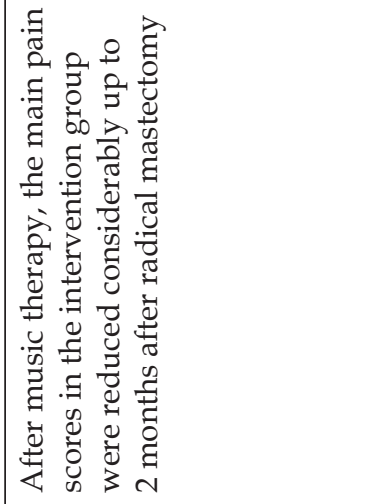 & 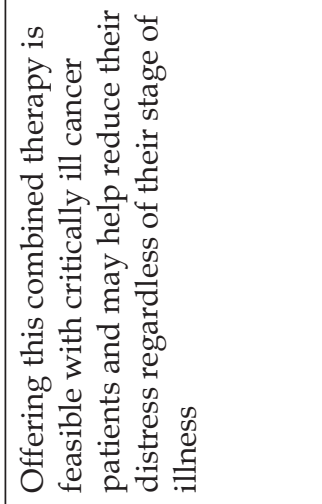 & 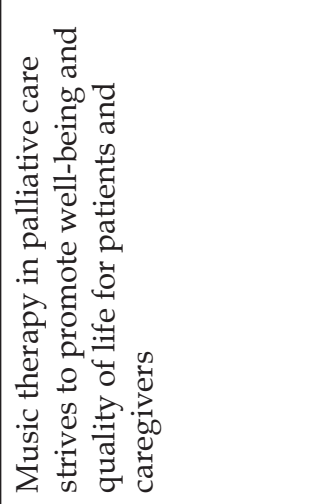 \\
\hline 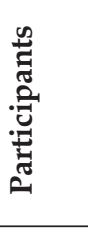 & 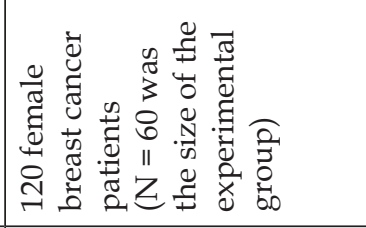 & 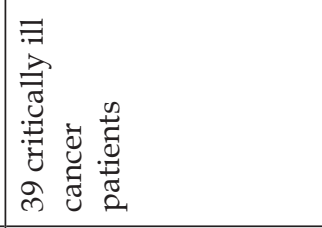 & 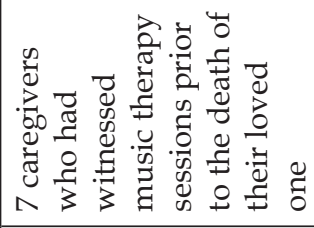 \\
\hline 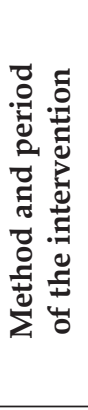 & 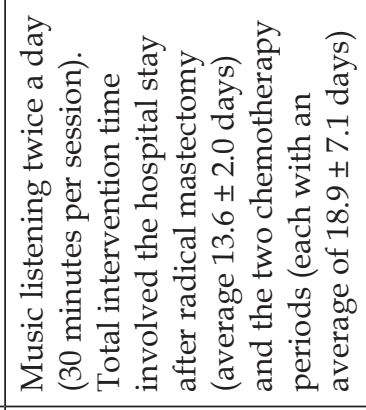 & 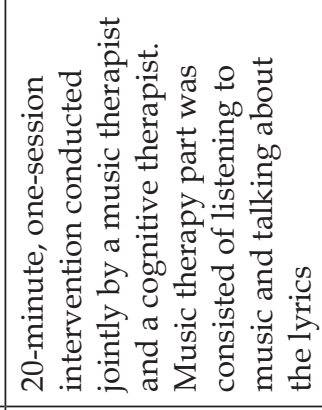 & 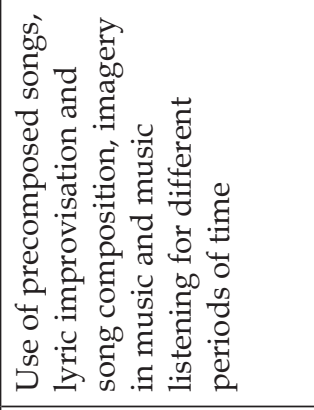 \\
\hline 塄 & 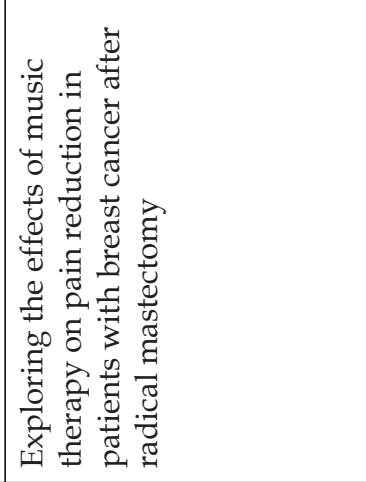 & 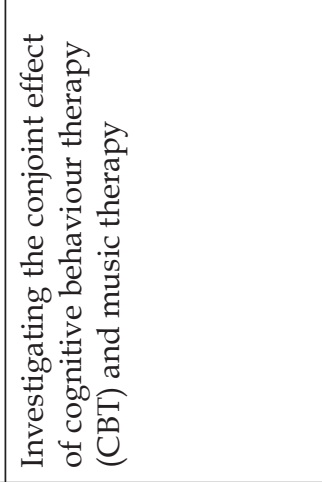 & 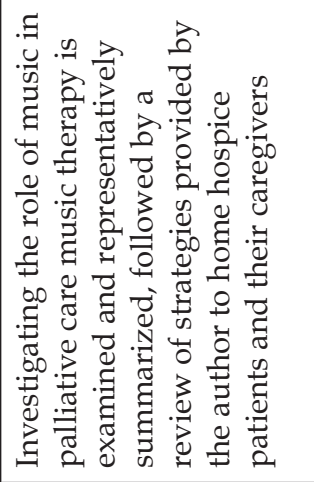 \\
\hline 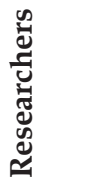 & 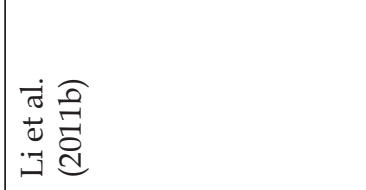 & 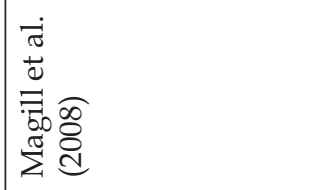 & 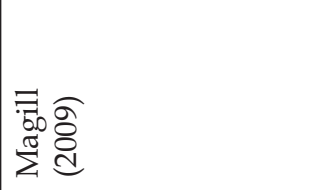 \\
\hline
\end{tabular}




\begin{tabular}{|c|c|c|c|}
\hline 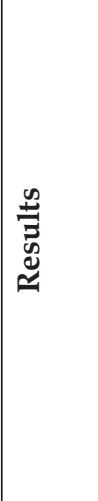 & 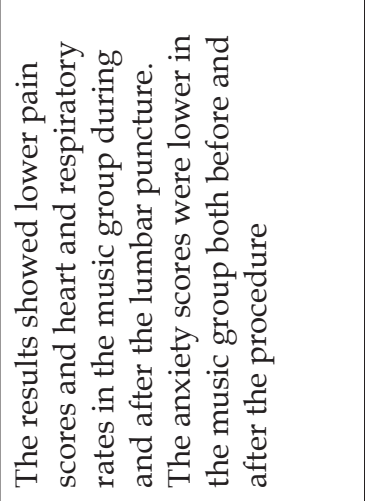 & 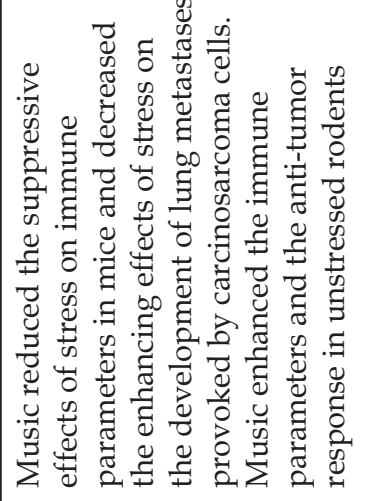 & 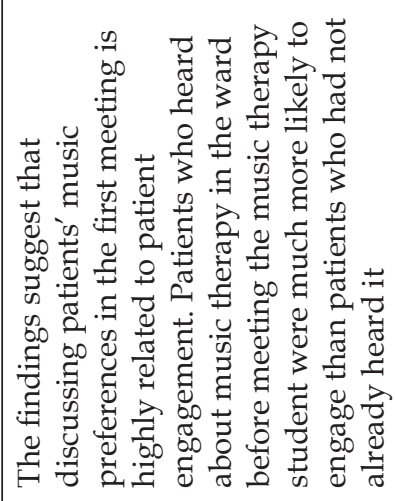 \\
\hline 苞 & 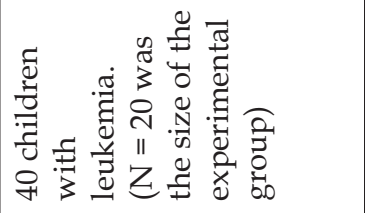 & 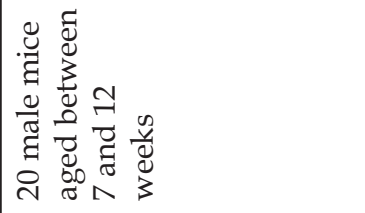 & 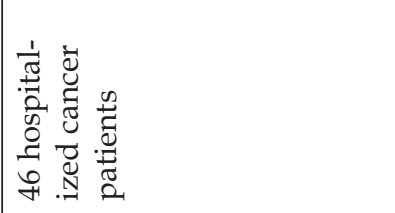 \\
\hline 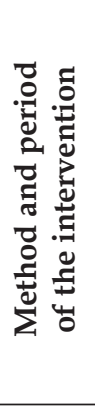 & 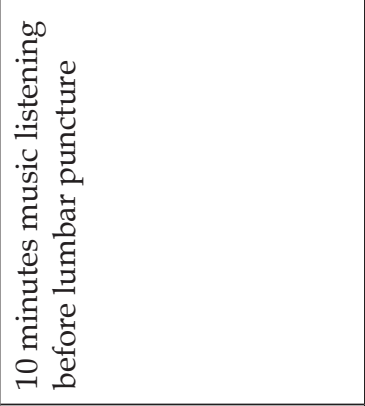 & 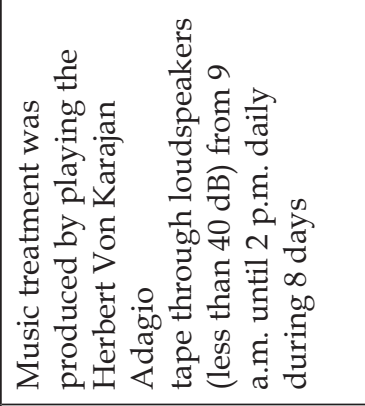 & 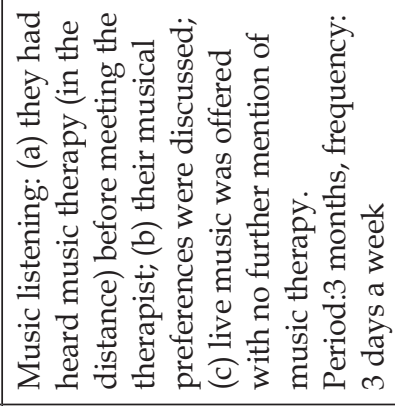 \\
\hline 灵 & 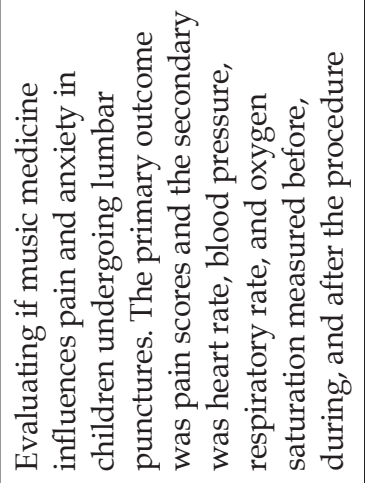 & 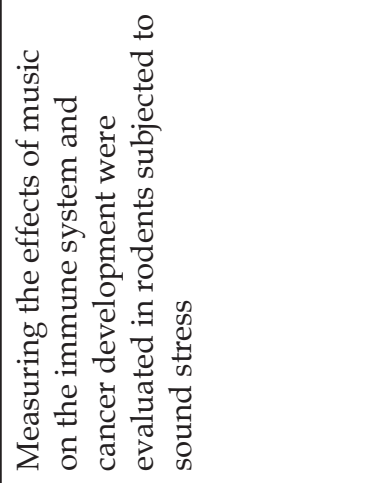 & 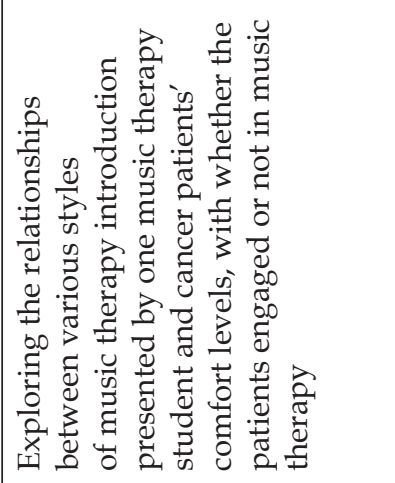 \\
\hline 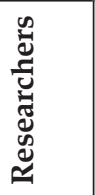 & 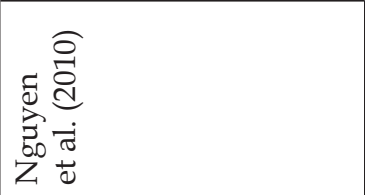 & 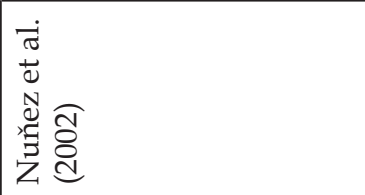 & 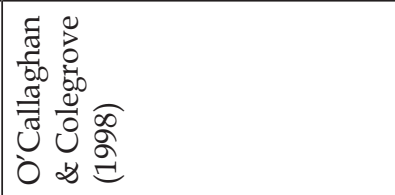 \\
\hline
\end{tabular}




\begin{tabular}{|c|c|c|}
\hline 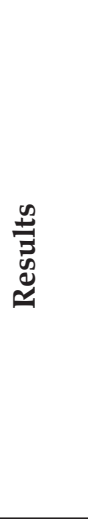 & 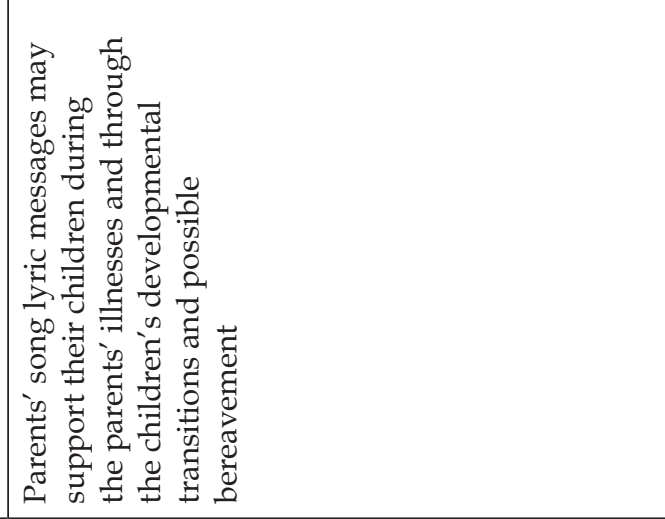 & 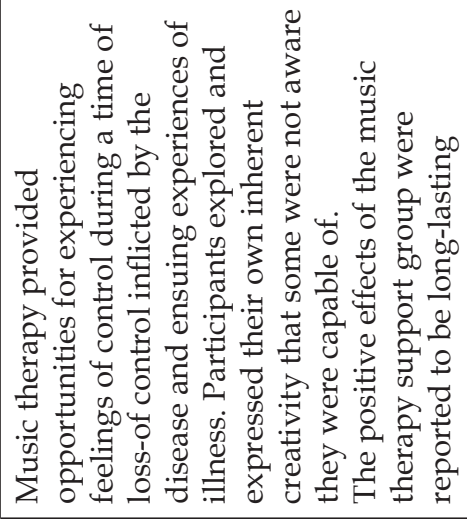 \\
\hline 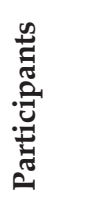 & 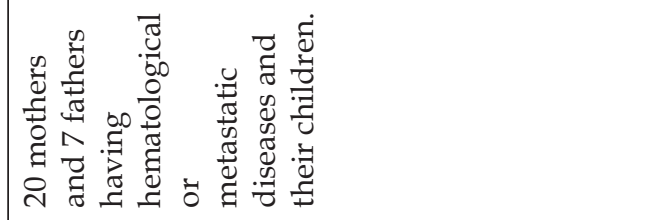 & 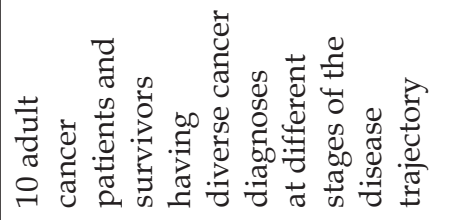 \\
\hline 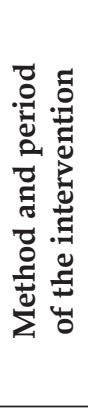 & 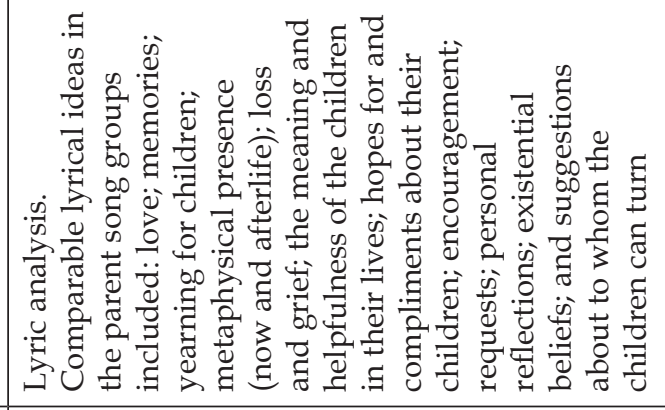 & 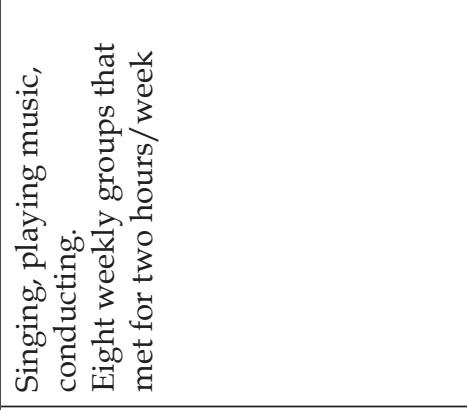 \\
\hline 寻 & 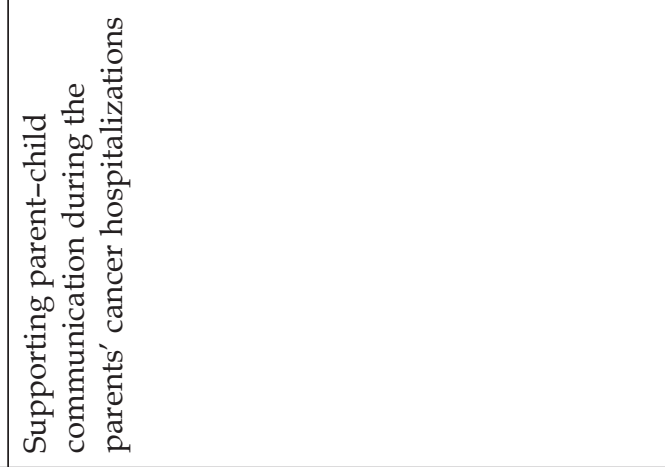 & 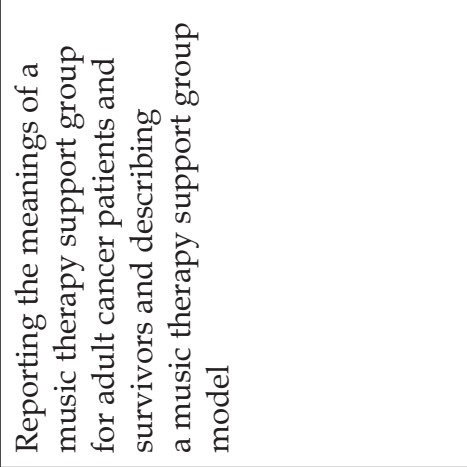 \\
\hline 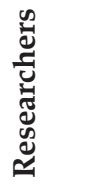 & 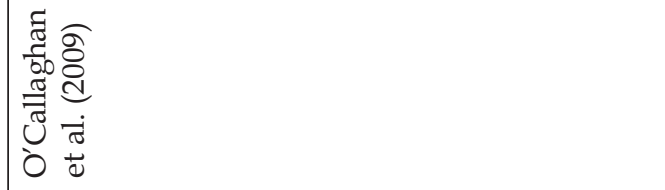 & 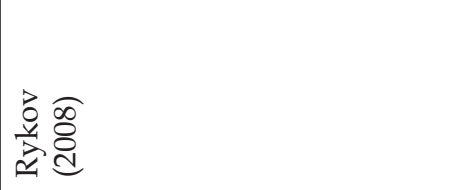 \\
\hline
\end{tabular}




\begin{tabular}{|c|c|c|c|}
\hline & 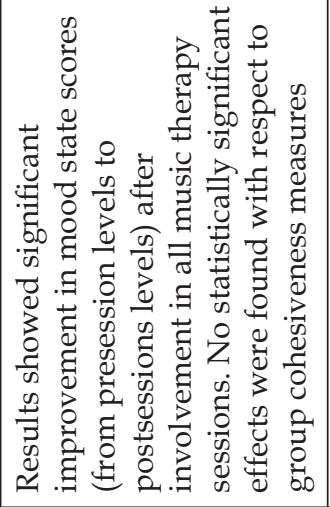 & 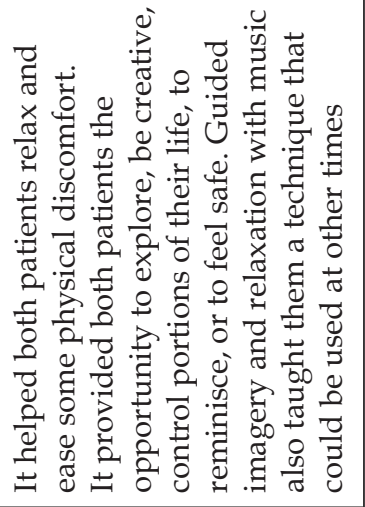 & 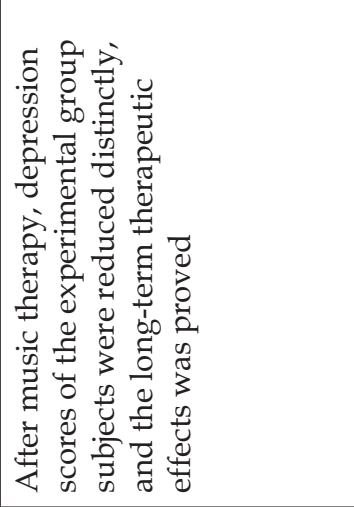 \\
\hline 苞 & 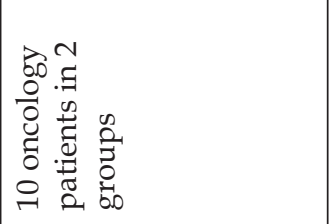 & 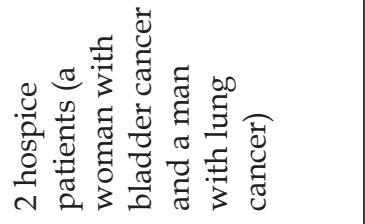 & 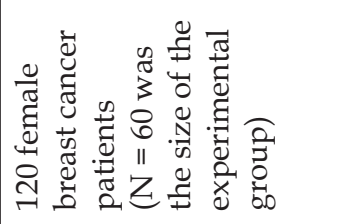 \\
\hline 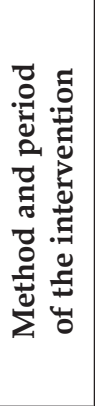 & 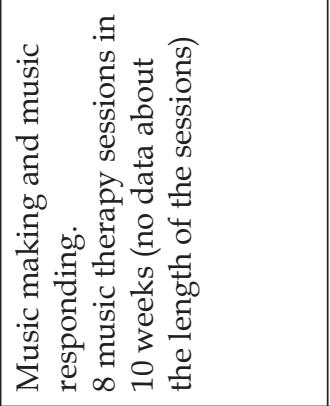 & 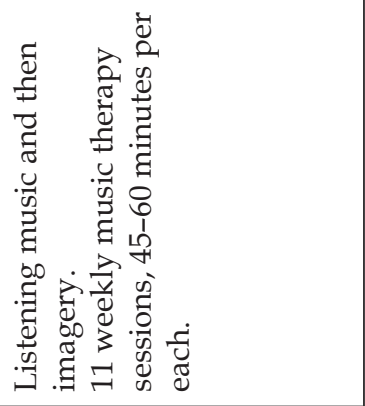 & 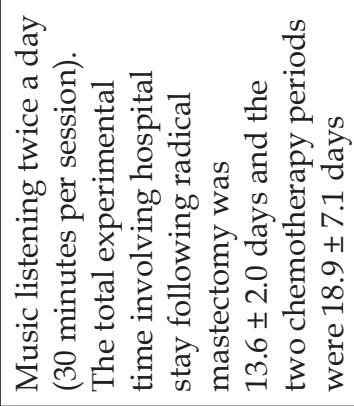 \\
\hline 灵 & 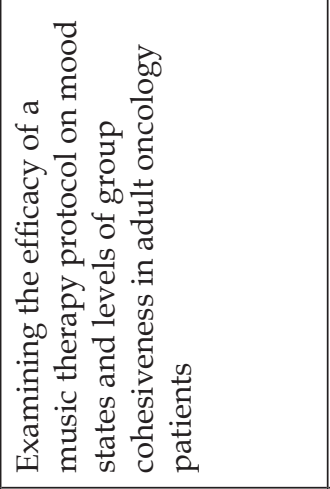 & 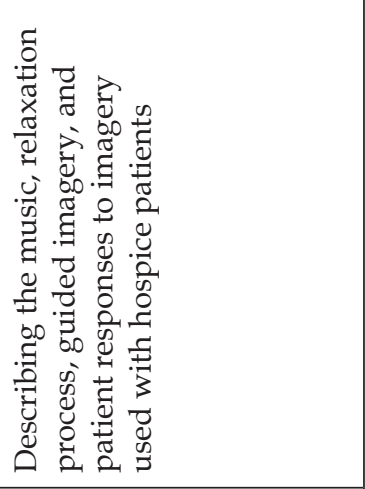 & 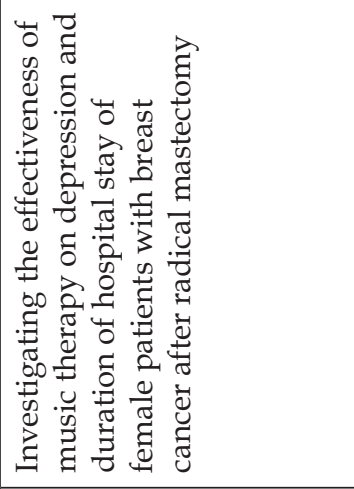 \\
\hline 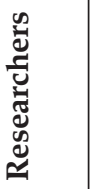 & 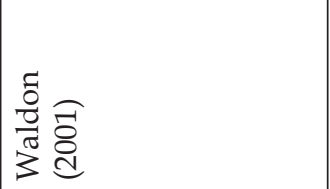 & 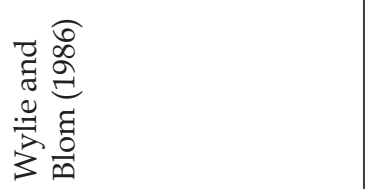 & 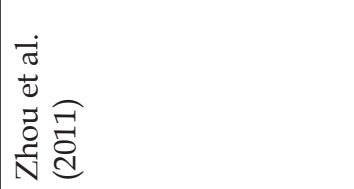 \\
\hline
\end{tabular}




\section{Conclusion}

Although this article cannot be considered as a systematic review the research evidences point out the diverse application opportunities of music in the course of treating cancer patients. Making comparison the research works mentioned above is quite challenging for many reasons. First, the methodological quality of the interventions varies considerably. Secondly, a large portion of the literature refers to relatively few participants. Thirdly, the studies reviewed assess quite different interventions and it makes the comparison relatively difficult. Fourthly indicators used to measure the success of intervention were mostly surveys and self-report questionnaires. No studies were found documenting a relationship between music therapy interventions and costs of care. Nevertheless according to the results of studies processed in this review it can be ascertained that music therapy can be suggested as a supportive treatment for cancer patients. It can improve the quality of life, provide psychosocial, emotional and physical aid for children and adults having cancer, moreover it is suitable even for rebuilding family connections. Music itself may have therapeutic effects nevertheless when it is used in therapeutic circumstances under the control and by qualified music therapists the supportive effect to cancer treatment can be secured. Music therapy can be applied alone or together with other therapies. Active and receptive forms are also suggested in treatment of children, adults and even family members of cancer patients. The sessions can make people suffering from cancer to feel "real human beings" again.

\section{References}

Addington-Hall, J. (2013). The legacy of cancer on depression and anxiety. Lancet Oncology, 14(8), 675-676.

Bailey, L.M. (1983). The effects of live music versus tape-recorded music on hospitalized cancer patients. Music Therapy, 11(1), 17-28.

Bailey, L.M. (1984). The use of songs in music therapy with cancer patients and their families. Music Therapy, 4(1), 5-17.

Barrera, M. E., Rykov, M. H., \& Doyle, S. L. (2002). The effects of interactive music therapy on hospitalized children with cancer: a pilot study. Psychooncology, 11(5), 379-388.

Binns-Turner, P.G., Wilson, L.L., Pryor, E.R., Boyd, G.L., \& Prickett, C.A. (2011). Perioperative music and its effects on anxiety, hemodynamics, and pain in women undergoing mastectomy. American Association of Nurse Anesthetists, 79(4), S21-S27.

Blake, R. L., \& Bishop, S. R. (1994). The Bonny Method of Guided Imagery and Music (GIM) in the treatment of post-traumatic stress disorder (PTSD) with adults in the psychiatric setting. Music Therapy Perspectives, 12(2), 75-79. 
Bonny, H.L. (1980). GIM therapy: Past, present, and future implications (GIM Monograph No. 3). Salina, KS: The Bonny Foundation

Brodsky, W. (1989). Music therapy as an intervention for children with cancer in isolation rooms. Music Therapy, 8(1), 17-34.

Burns, D.S. (2001). The effect of the Bonny Method of Guided Imagery and Music on the mood and life quality of cancer patients. Journal of Music Therapy, 38(1), 51-65.

Chen, L.C., Wang T.F., Shih, Y.N., \& Wu, L.J. (2013). Fifteen-minute music intervention reduces pre-radiotherapy anxiety in oncology patients. European Journal of Oncology Nursing, 17(4), 436-441.

Chuang, C.-Y., Han, W.-R., Li, P.-C., \& Young, S.-T. (2010). Effect of music therapy on subjective sensations and heart-rate variability in treated cancer survivors: A pilot study. Complementary Therapies in Medicine, 18(5), 224-226.

Chuang, C.-Y., Han, W.-R., Li, P.-C., \& Young, S.-T. (2011). Effect of long-term music therapy intervention on autonomic function in anthracycline-treated breast cancer patients. Integrative Cancer Therapies, 10(4), 312-316.

Daveson, B.A. (2001). Music therapy and childhood cancer: coals, methods, patient choice and control during diagnosis, intensive treatment, transplant and palliative care. Music Therapy Perspectives, 19(2), 114-120.

Daykin, N., McClean, S., \& Bunt, L. (2007). Creativity, identity and healing: participants' accounts of music therapy in cancer care. Journal of Alternative and Complementary Medicine, 18(4), 402-407.

Fagen, T.S. (1982). Music therapy in the treatment of anxiety and fear in terminal pediatric patients. Music Therapy, 2(1), 13-23.

Gasenzer, E.R., \& Neugebauer, E.A. (2011). The relations between music and medicine in history and present. Deutsche Medizinische Wochenschrift, 136(51-52), 2644-2651.

Gutgsell, K.J., Schluchter, M., Margevicius, S., DeGolia, P.A., McLaughlin, B., Harris, M., Mecklenburg, J., \& Wiencek, C. (2013). Music therapy reduces pain in palliative care patients: a randomized controlled trial. Journal of Pain and Symptom Management, 45(5), 822-831.

Huang, S.-T., Good, M., \& Zauszniewski, J.A. (2010). The effectiveness of music in relieving pain in cancer patients: A randomized controlled trial. International Journal of Nursing Studies, 47(11), 1354-1362.

Kemper, K.J., Hamilton, C.A., McLean, T.W., \& Lovato, J. (2008). Impact of music on pediatric oncology outpatients. Pediatric Research, 64(1), 105-109.

Kollár, J. (2007). Zeneterápia a daganatos betegek kezelésében [Music therapy with cancer patients]. Lege Artis Medicinae, 17(11), 828-832.

Kruse, J. (2003). Music therapy in United States cancer settings: recent trends in practice. Music Therapy Perspectives, 21(2), 84-88.

Lai, H.-L., Li, Y.-M., \& Lee, L.-H. (2012). Effects of music intervention with nursing presence and recorded music on psycho-physiological indices of cancer patient caregivers. Journal of Clinical Nursing, 21(5-6), 745-756.

Lai, W.-S., Chao, C.-S. C., Yang, W.-P., \& Chen, C.-H. (2010). Efficacy of guided imagery with theta music for advanced cancer patients with dyspnea: a pilot study. Biological Research for Nursing, 12(2), 188-197.

Lee, E.J., Bhattacharya, J., Sohn, C., \& Verres, R. (2012). Monochord sounds and progressive muscle relaxation reduce anxiety and improve relaxation during chemotherapy: A pilot EEG study. Complementary Therapies in Medicine, 20(6), 409-416. 
Li, X.-M., Zhou, K.-N., Van, H., Wang, D.-L., \& Zhang, Y.-P. (2011a) Effects of music therapy on anxiety of patients with breast cancer after radical mastectomy: a randomized clinical trial. Journal of Advanced Nursing, 68(5), 1145-1155.

Li, X.-M., Yan, H., Zhou, K.-N., Dang, S.-N., Wang, D.-L., \& Zhang, Y.-P. (2011b). Effects of music therapy on pain among female breast cancer patients after radical mastectomy: results from a randomized controlled trial. Breast Cancer Research and Treatment, 128(2), 411-419.

Magill, L. (2009). The meaning of the music: the role of music in palliative care music therapy as perceived by bereaved caregivers of advanced cancer patients. American Journal of Hospice \& Palliative Care, 26(1), 33-39.

Magill, L., Levin, T., \& Spodek, L. (2008). One-session music therapy and CBT for critically ill cancer patients. Psychiatric Services, 59(10), 1216.

McNair, D.M., Lorr, M., \& Doppleman, L.F. (1992). EdITS manual for the Profile of Mood States. San Diego, CA: Educational and Industrial Testing Service.

Mowatt, K. (1967). Background music during radiotherapy. The Medical Journal of Australia, 1(4), 185-186.

Nguyen, T.N., Nilsson, S., Hellstrom, A.L., \& Bengtson, A. (2010). Music therapy to reduce pain and anxiety in children with cancer undergoing lumbar puncture: a randomized clinical trial. Journal of Pediatric Oncology Nursing, 27(3), 146-155.

Nuňez, M.J., Maňá, P., Liňares, D., Riveiro, M.P., Balboa, J., Suárz-Quintanilla, J., et al. (2002). Music, immunity and cancer. Life Sciences, 71(9), 1047-1057.

Nyer, M., Doorley, J., Durham, K., Yeung, A.S., Freeman, M.P., Mischoulon, D. (2013). What is the role of alternative treatments in late-life depression? Psychiatric Clinics of North America, 36(4), 577-596.

O'Callaghan, C., \& Colegrove, V. (1998). Effect of the music therapy introduction when engaging hospitalized cancer patients. Music Therapy Perspectives, 16(2), 67-74.

O'Callaghan, C., O'Brien, E., Magill, L., \& Ballinger, E. (2009). Resounding attachment: cancer inpatients' song lyrics for their children in music therapy. Supportive Care in Cancer, 17(9), 1149-1157.

Padilla, G.V., Grant, M.M., Ferrell, B.R., Presant, C.A. (1996). Quality of Life-Cancer. In: B. Spilker (Ed.), Quality of life and pharmacoeconomics in clinical trials (301-308). Second edition. Philadelphia USA: Lippincott-Raven Publishers

Renz, M., Schutt Mao, M., \& Cerny, T. (2005). Spirituality, psychotherapy and music in palliative cancer care: research projects in psycho-oncology at an oncology center in Switzerland. Support Care Cancer, 13(12), 961-966.

Rykov, M.H. (2008). Experiencing music therapy cancer support. Journal of Health Psychology, 13(2), 190-200.

Slivka, H., \& Magill, L. (1986). The conjoint use of social work and music therapy in working with children of cancer patients. Music Therapy, 6(1), 30-40.

Waldon, E.G. (2001). The effects of group music therapy on mood states and cohesiveness in adult oncology patients. Journal of Music Therapy, 38(3), 212-238.

Wylie, M.E., \& Blom, R.C. (1986). Guided Imagery and Music with hospice patients. Music Therapy Perspectives, 3(1), 25-28.

Zhou, K.N., Li, X.M., Yan, H., Dang, S.N., \& Wang, D.L. (2011). Effects of music therapy on depression and duration of hospital stay of breast cancer patients after radical mastectomy. Chinese Medical Journal, 124(15), 2321-2327. 


\title{
Conflicts of Interests Statement
}

The author declares that he has no conflict of interest.

\section{Zene alkalmazása rákos betegek kiegészítő kezeléseként}

\author{
KOLLÁR JÁNOS
}

Elméleti háttér: A zene kiegészítő terápiaként való alkalmazása rugalmas, kliensközpontú, adaptív és non-invazív eljárás. A zene többféle alkalmazásban használható a distressz, krónikus fájdalom, szorongás és depresszió kezelése során.

Cél: E tanulmány célja felhívni a figyelmet a zene daganatos betegek kezelése során kiaknázható kiegészítő, szupportív kezelési lehetőségeire. A cikk eme lehetőségek alkalmazásának szélesebb spektrumát kívánja bemutatni.

Módszerek: Keresést végeztem a Journal of Music Therapy, a Music Therapy, valamint a Music Therapy Perspectives számaiban. A keresést kiterjesztettem a PubMed és a Web of Knowledge olyan, angol nyelvú cikkeire is, amelyek címében szerepeltek a "music" és "cancer" vagy "music" és "psychooncology", vagy "music" és "oncology", vagy "music" és "tumor", vagy "music" és "tumour" szavak. A keresést 2013-ban lezártam. A cikkeket a zene daganatos betegek kezelésében betöltött szerepét illető relevancia szerint szúrtem. Relevánsnak ítéltem azokat a cikkeket, amelyek: 1 . a zene daganatos betegek esetében történó bármilyen módon történő alkalmazásáról szóltak, és 2. eredeti kutatási eredményt tartalmaztak, így a review jellegú cikkeket nem vettem figyelembe. Összesen 61 cikket találtam, amelyek közül 25 megfelelőnek bizonyult ahhoz, hogy szerepeljen a jelen áttekintésben. Az adatok elemzése az alábbi kritériumokon alapult: a) a zenei beavatkozás célja a daganatos betegek esetén, b) az alkalmazott módszer és a beavatkozás ideje, c) a vizsgálatban részt vevő betegek száma és d) eredmények.

Eredmények: Szignifikáns javulás tapasztalható a szupportív kezelésként zenei beavatkozásban részesülő daganatos betegek életminőségében. A zeneterápia mind aktív, mind receptív formái sikeresen alkalmazhatóak akár önmagukban, akár más terápiákkal a szupportív kezelés részeként.

Következtetés: A képzett zeneterapeuták által, terápiás körülmények között alkalmazott zenei beavatkozások javasolhatóak szupportív kezelési céllal daganatos betegek kezelése során.

Kulcsszavak: zene, rák, distressz, relaxáció, depresszió, mellrák, masztektómia 